
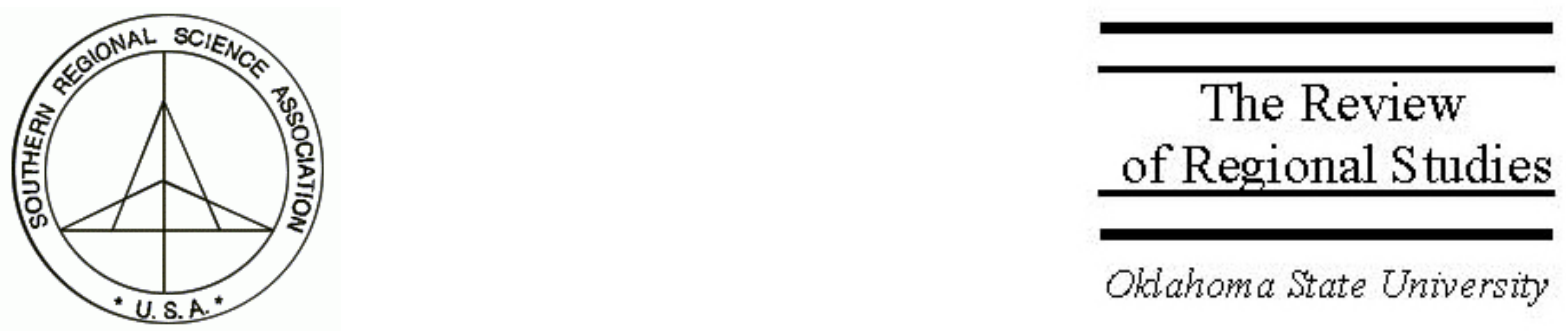

\title{
Pioneers of Rural Sprawl in the Rocky Mountain West*
}

\author{
Stephan Weiler \\ Center for the Study of Rural America, Federal Reserve Bank of Kansas City \\ Kansas City, MO 64198, email: Stephan.Weiler@kc.frb.org \\ David Theobald \\ Natural Resource Ecology Laboratory, Colorado State University, CSU Campus Mail 1771, \\ Fort Collins, CO 80523-1771, email: David.Theobald@colostate.edu
}

\begin{abstract}
Urban sprawl has been criticized for its disproportionate impact on the environment. Yet urban areas are in fact less land-intensive than recent rural development patterns. Residential first-movers into such virgin areas may spark waves of ensuing development without incorporating the true social costs of their pioneering. This paper first explores both benefit/cost and game-theoretic frameworks for understanding the private strategies and social implications of such pioneer developments. Evidence regarding regional land-use intensities, path-dependence of rural development, and accumulating social costs of "rural sprawl" are then presented to highlight the relevance of this paper's theoretical perspective in the Rocky Mountain West. The primary conclusion of the combined theoretical and empirical work is that pioneering development in innovative rural locations is likely relative to the social optimum, suggesting a rationale for public policy.
\end{abstract}

\footnotetext{
* The views are those of the authors and do not necessarily reflect the positions of the Federal Reserve Bank of Kansas City or the Federal Reserve System.
} 


\section{INTRODUCTION}

Previous work determined that pioneering development in urban areas can exhibit substantial positive spillovers (Weiler 2000). However, since pioneers tend to face all the costs and risks of such investment while enjoying only a slice of the eventual rewards, there will tend to be a shortage of pioneers in redeveloping urban areas. However, development can potentially have negative spillovers over time as well. Eventual over-success of pioneering efforts has led to the current policy concerns of urban sprawl (Brueckner 2000), which is commonly defined as auto-dependent growth at the fringe of urban areas (Duany, Plater-Zyberk, and Speck 2000) that contributes to the loss of agricultural resources and wildlife habitat.

Yet urban development, even urban sprawl, tends to be considerably less land-intensive than residential development in rural areas, particularly in the western United States. With improvements in road transport and increased telecommuting, the quality of life of more isolated areas has attracted a new wave of rural development (Riebsame, Gosnell, and Theobald 1996; Baron, Theobald, and Fagre 2000). In contrast to low-density agricultural and ranching land-use, pioneering residential choices in previously undeveloped rural locations can quickly cause an expanding cluster of development. Such "innovative" initial development decisions can thus be seen as initiating a pathdependent cycle of ensuing development where pioneers effectively lead the way to further growth. Those who first move into those areas tend to receive most of the initial benefits of solitary living. However, the pioneer's initial benefits from solitude may in fact be dwarfed by the accumulating social costs of sprawling development, while the first-movers themselves enjoy ever smaller slices of the now shared benefits of rural bliss.

In this paper we argue that the divergence between "first-mover" (pioneer) benefits relative to eventual accumulating social costs may lead to snowballing low-density development in isolated rural areas to the detriment of overall social welfare. Both the low-density and path-dependence of rural development lead to accelerating rural sprawl in newly pioneered areas. The principal reason social costs diverge from the narrower private cost calculus is the accumulating broader external ecological costs. Implicit infrastructural subsidies further widen the gap between privately versus socially optimal outcomes. Such a situation suggests that pioneers, who face only a small portion of these costs, will tend to over-invest in low-density rural areas.

Section 2 considers the divergence of private benefits and social costs from the perspective of a private first-mover, followers, and social welfare. A game-theoretic model is provided to help understand private investment decisions, clarifying why pioneers are overly likely in isolated areas relative to a benchmark social optimum. Using Colorado as a focus, the third section reviews empirical and case study evidence for our hypotheses regarding relative land-use intensity, pathdependence of rural development, and implications for accumulating external costs. The fourth section concludes with policy implications. 


\section{RESIDENTIAL PIONEERS AND THEIR FOLLOWERS}

\subsection{The Benefits and Costs of Rural Bliss}

The mobility advantages of increasingly efficient road transportation and the advent of telecommuting have allowed workers to spatially divorce their place of work from their place of residence. The transition from a goods-producing economy to increasing service orientation provides considerably greater flexibility for residential decisions based on quality-of-life now that workers are not tied to place-specific work locations (Nelson 1992; Power 1996). Such workers tend to be highly skilled, and many prefer the amenities found in more rural settings. These tendencies reinforce the high income elasticity of natural amenity preferences (Cromartie and Nord 1997), with wealthier individuals valuing these characteristics more highly than those with lower incomes.

In deciding whether to move to a new undeveloped location, the pioneer will weigh her private benefits against the private costs. If the former exceeds the latter, the pioneer will relocate to a new area. Note that these benefit/cost contrasts are assessed on a relative basis against alternatives such as those offered by urban areas. Constant absolute benefits from a given rural site may draw relatively more pioneers as urban areas face greater congestion and lower quality of life. Evidence indicates that precisely such pioneering is taking place in the Rocky Mountain West region as relative amenity tradeoffs between urban and rural areas favor the latter (Riebsame, Gosnell, and Theobald 1997; Wilkin and Iams 1990).

In general, it is readily apparent that this paper's benefit/cost perspective is only relevant to a subsection of the population with preferences for more isolated rural living. Those who don't move to such locations could be assumed to have marginal private benefits for such locations to be well below the household's marginal costs and simply choose to remain in the cities. However, as long as some potential residents value the more isolated rural lifestyles, residential migration to previously undeveloped rural locations is possible. As will be shown, not only is such migration occurring, but the private and social optima for associated rural residential development are likely to diverge as accumulating social costs of development are greater than the private cost considerations of pioneers and followers.

Assuming a general preference for the tranquility of rural living among those considering such options, the private benefits of a new undeveloped location will be greatest for those successfully finding an isolated nest, specifically those who move first into an otherwise undeveloped area. The fact that such amenities are likely to be highly income-elastic implies that those most able to undertake the costs of pioneering (i.e., the wealthy) are also those who are most likely to seek such new sites. The private costs for these pioneers is likely to be higher than for followers, given the need to support the high average costs of single-strand infrastructure (e.g., utilities, roads) to their development or the development of useful alternatives (e.g., solar power, wells, etc.). Nevertheless, evidence of movement into previously undeveloped areas itself indicates that private benefits for pioneers exceed private costs.

Given that a pioneer has illuminated an area of relative tranquil bliss that has positive net benefits for rural living, followers are likely to arrive over time. Marginal private benefits for the 
followers will decline, since they are now sharing a new area. The relatively undeveloped nature of the location, however, implies that immediate followers can enjoy nearly the same blissful pleasures as the pioneer. Thus, incremental private benefits to each additional follower may not decline substantially.

In contrast, follower costs are likely to drop significantly as pioneers literally pave the way for less costly ensuing residential development. " . . [T] he pioneer fringe of urban development ... play[s] an important role in establishing land uses. They are the focus of further growth, for they often blaze the paths that subdividers follow. However, later development consists of clustered growth rather than random additions in formerly nonurban zones" (Pyle, 1985, p. 34). Once pioneers have innovated infrastructure options for the new location, followers' may benefit from significant marginal reductions in the costs they face relative to the pioneer. The reduction may be discrete and especially significant if infrastructural innovation is an important factor in local residential development or if the pioneer reveals the residential potential of an especially unknown rural area, which saves followers especially high search costs. The cost reductions may be explicit, such as in the sharing of a road or telecommunications link leading to Pyle's clustered development, or informational, such as lessened search costs or the feasibility of satellite connection options. Again, it is the "revelation" of the economic viability of a pristine area in terms of net positive benefits that is the key spark to the ensuing wave of rural development.

The total private benefits and costs of rural location decisions can be summarized by

$$
\begin{aligned}
& B=F\left[\text { Population in Rural Area], with } B^{\prime}(P)>0 \text { and } B^{\prime \prime}(P)<0,\right. \\
& C=F[\text { Population in Rural Area }] \text {, with } C^{\prime}(P)>0 \text { and } C^{\prime \prime}(P)<0 .
\end{aligned}
$$

Since the decision of the marginal mover, either pioneer or follower, is the crucial factor in determining the extent of development, the marginal benefit/cost graphic in Figure 1 is particularly relevant. By revealed preference, initial private benefits exceed private costs for the first-mover; residential migration into such undeveloped locations indicates that net positive benefits must have existed for such pioneering to take place. Marginal benefits initially decline less rapidly than marginal costs (thus, $C^{\prime \prime}(P)<B^{\prime \prime}(P)<0$ ), especially for immediate followers; only minor incremental reductions in benefits from still-isolated shared rural living are almost certainly smaller than the discrete drops in explicit (e.g., cluster) and implicit (e.g., informational) development costs. However, these initial cost advantages are eventually overtaken by the steady decrease in benefits through increased local crowding, thus $B^{\prime \prime}(P)<C^{\prime \prime}(P)<0$. The privately optimal level of development occurs at the point where the marginal private cost and marginal private benefits curves intersect at $P_{p r v}$.

In contrast to the pioneer/follower assessment of private benefits against costs, the social desirability of such pioneering depends on social benefits exceeding social costs. In the case of rural pioneering, social benefits are equal to the private benefits of the residents since they alone accrue value from their location decision. However, these first-movers are unlikely to face the full social costs (namely, private costs plus additional external spillovers) of these choices. As will be argued, external spillovers cause social costs to exceed social benefits, indicating that purely private decision 


\section{FIGURE 1}

Social versus Private Benefits/Costs of Rural Residency

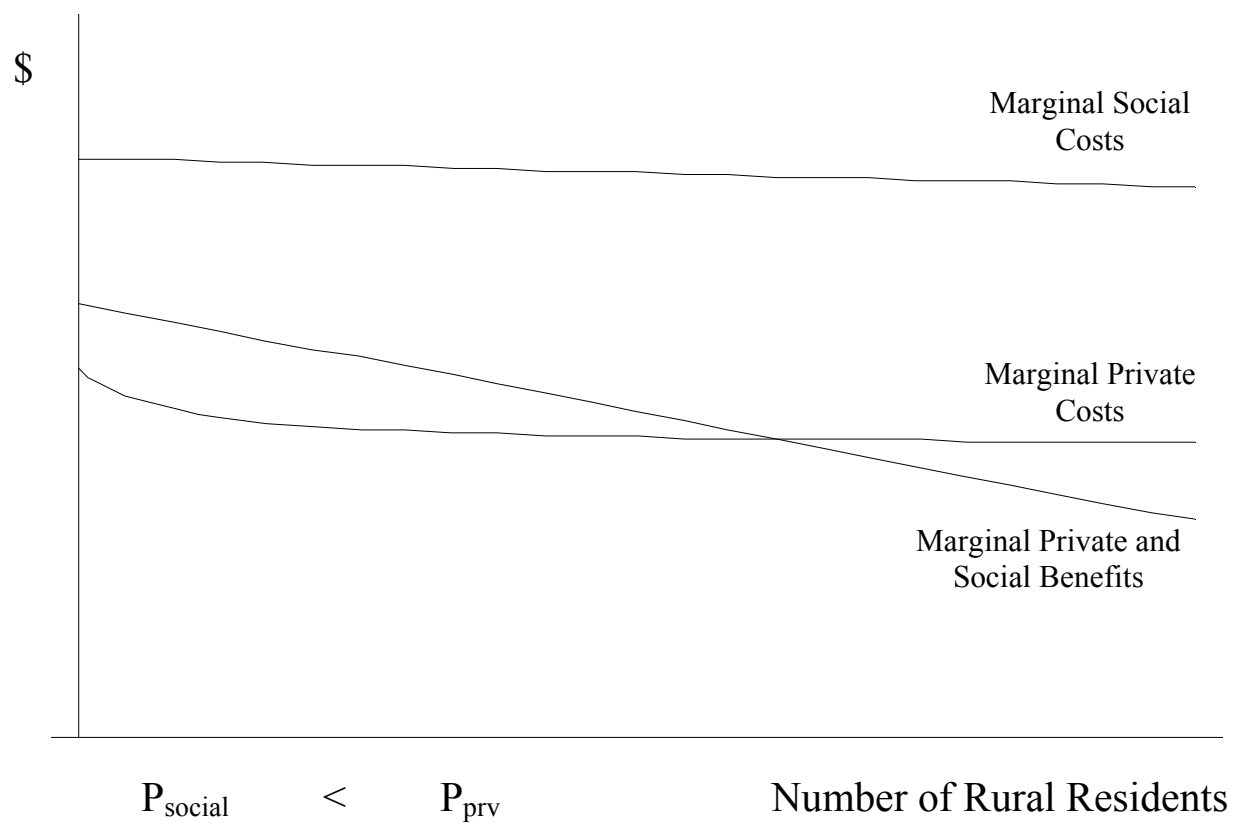

making in rural land use can reduce social welfare.

Additional social costs beyond those faced by the private pioneers stem from two sources, both resulting in forms of market failure where private and social optima diverge. The first source of external costs stems from average versus marginal cost pricing of most infrastructure and public services. The marginal costs of providing public infrastructure (i.e., utilities, mail service, school buses) for outlying areas are considerably greater than for more concentrated areas of development (Blair 1995), yet average cost pricing effectively forces higher-density development to subsidize lower-density areas. While some of these additional costs may be borne by the pioneer, such as travel to post office boxes and greater need for private transportation, it is likely that at least some of these costs will be implicitly subsidized by other more urban, and thus less costly, consumers. While this cost differential is not typically considered to be an externality, it nevertheless stems from a difference between private costs perceived by the resident and overall costs to society. Equitable pricing structures for certain services may in fact result in considerably biased subsidies towards the rural wealthy, yet follows in the tradition of "fair" pricing of widely consumed goods and services (e.g., Kahnemann, Knetsch, and Thaler 2000).

The second source of social costs is the accumulating opportunity costs of development on local ecosystems and conservation values. Initial residential development can cause habitat loss, degradation, and fragmentation by introducing exotic species, disturbing current wildlife habitats, and suppressing natural ecological processes (Theobald, Miller, and Hobbs 1997). Development that follows this pioneer will continue to add to the negative external spillovers to the local environment. In fact, certain actions by rural residents to circumvent infrastructural constraints, such 
as increased use of private automobiles, may in fact heighten the ecological costs of such development. While both pioneers and followers appreciate the services an intact ecosystem provides them, much of the ecosystem damage that occurs is often not tangible nor of direct benefit to the residents (Hansen et al. 2002). Furthermore, environmental degradation can quickly become exponential as ecosystem interdependencies are disrupted in a dynamic analogous to Baumol's classic cumulative causation perspective of urban deterioration (Baumol 1963).

The fire seasons in 2000 and 2002 in the Rocky Mountain West have underlined such costs. The rapidly increasing number of forestland fringe residents not only increases the probability of accidental wildfires but also increase the likely firefighting costs as well as damage from such blazes. For example, from 1990 to 2000 over 2.1 million people moved into the forest fringe, resulting in a total residential forest population of over 12.2 million (Theobald 2002). These costs, however, are distributed widely since much of the containment and redevelopment costs are borne by state and federal government. Thus neither pioneers nor settlers face the full social costs of their innovative location decisions.

Settlers nestle themselves near the pioneer. Meanwhile, the social costs of each additional mover, who only considers her own narrow private costs, now accumulate. Environmental and ecosystem damage will grow with each additional mover, who not only avoids facing her own impact on the area but also the accumulating effect of the procession of followers seeking rural bliss. The pioneering effort of the first-mover directly leads to this snowball, given the path-dependence of ensuing development based on the revelation of the new area by the pioneer. Marginal social costs therefore may decline only slightly, may in fact remain roughly constant, and could even increase for each incremental resident depending on the fragility and interdependence of the ecosystem; for ease of exposition, we posit the conservative first scenario. Using a parallel system to the private benefit/cost calculus above,

$$
\begin{aligned}
& B_{s}=F \text { [Population in Rural Area], with } B_{s}^{\prime}(P)>0 \text { and } B_{s}^{\prime \prime}(P)<0, \\
& C_{s}=F \text { [Population in Rural Area], with } C_{s}^{\prime}(P)>0 \text { and } C_{s}^{\prime \prime}(P)<0 .
\end{aligned}
$$

The critical contrast with the private perspective is that $C_{s}^{\prime}(P)>C^{\prime}(P)>0$, namely that private costs of incremental residents are smaller than their social costs.

Figure 1 summarizes the marginal benefits and costs for both the private agents and broader social welfare. Initial private (and social) benefits just exceed private costs for the first-mover. Additional private costs decrease more rapidly than benefits for followers. Marginal social costs are likely to stay constant or decline only slowly as each additional resident continues to impact both the environment and add to infrastructural costs. These additional social costs increasingly exceed private costs, given the two types of external spillovers described above. Thus, by illuminating the way for followers, the pioneer ensures a growing accumulation of social costs over benefits. The pioneering spark in fact causes an increasing loss in social welfare. In the case of Figure 1, the socially optimal amount of development would be zero $\left(P_{\text {social }}\right)$, as any development's marginal social cost exceeds its marginal social benefit. More generally, given equality between private and social benefits, socially optimal development will always be less than privately optimal development since $C_{s}^{\prime}(P)>C^{\prime}(P)$. 


\subsection{Game-Theoretic Model}

A two-person non-cooperative game theory model can be helpful in understanding the critical first-mover decision, similar to a structure used to describe pioneers in urban redevelopment (Weiler 2000). Figure 2 summarizes an extensive form game where each player makes a decision on whether to enter $(E)$ the rural area. No entry $(N)$ results in zero net change in utility. If a first-mover enters and finds that the benefits from isolation were not worth the costs of entering, utility losses totaling $-L$ will result. If a first mover enters and feels these benefits exceed the costs of entering, the first period's (monopoly) utility will be $M$, based on the innovative location's solitude. Further utility gains will depend on further entry. If the first-mover remains alone, $M$ will continue. Otherwise, a competitive utility level of $C$ will result for both entrants. This game is one of incomplete information where a probability is assigned to the uncertainty regarding the potential for relative bliss in this new area. In effect, this probability $p$ of uncovering a high-benefit isolated site makes the reality of imperfect information tractable (Harsanyi 1968).

This analysis initially focuses only on the private investor's benefits and costs, addressing the question of whether purely private actors will make such ground-breaking investments. If the rural area is successful, negative land-use spillovers may dwarf the private investor's own utility gains, but such broader losses do not deter individual pioneers. The prospects for a rural area thus depend on the understandably narrower interests of potential first-movers. For simplicity, risk neutrality is assumed, which allows a comparison of expected values to determine entry.

Given the game's subgame perfect solution to Figure 2, which applies each player's best combination of optimal moves at each decision node, the first mover will receive

$$
[p(M+C)]+[(1-p)(-L)]
$$

profits if she initially enters, derived from the monopoly then competitive utility she earns if the area is viable and the losses she incurs from non-viability. Both payoffs are weighted by the probability of viability. If she does not enter, she will receive

$$
p C
$$

by virtue of her second-round entry following an alternative successful pioneer. So, the condition for entry is

$$
[p(M+C)]+[(1-p)(-L)]>p C
$$

The solution is both simple and intuitive. A potential rural pioneer will only enter if she perceives the probability of success to be

$$
p>L /(M+L) .
$$




\section{FIGURE 2}

Two-Player Entry Decision in New Rural Location

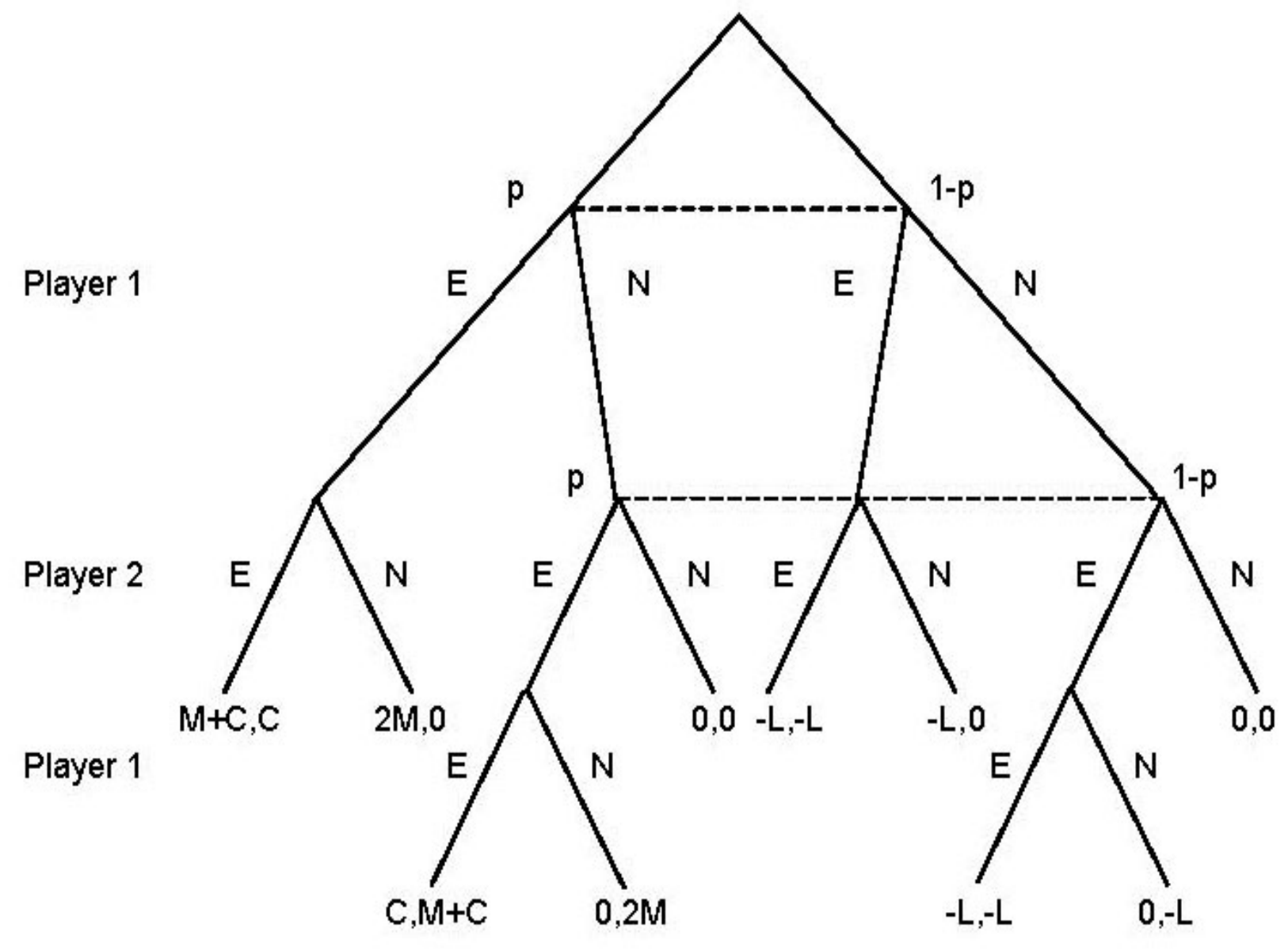

p : Viable area 1-p : Non-viable area E: Enter $\quad$ N: No entry

In other words, if $L$ is considerably smaller than the expected one-period (or short-term) "monopoly" utility, which seems realistic for those seeking solitude, rural pioneers are likely. Curious firstmovers want to rush into a place where they can enjoy at least short-term blissful isolation. Even if they are followed, they still can enjoy potentially sizable net utility gains.

However, pioneering may not be socially desirable. Negative spillovers on ecosystems' conservation values represent additional external social costs over those faced by the private investor. In addition, any implicit subsidy of private pioneering costs would also be included in such negative social spillovers, since other less dispersed and thus less costly sub/urban consumers would still face the remaining costs even if the pioneer does not. Using $S$ to signify such spillovers, entry is socially desirable if 


$$
[p(M-S)]+[(1-p)(-L)]>0 \text {. }
$$

Monopoly net utility $(M)$ is a social benefit, minus the infrastructural costs borne by others and the ecological costs of snowballing development, $S$. However, since competitive utilities are assumed to be equal to the net utility gains derived from (presumably less attractive but also less costly) alternative location choices, they are not included as a social benefit.

Social planners would therefore have a higher viability threshold,

$$
p>L /(M+L-S)>L /(M+L)
$$

than that of the potential private pioneer. While private investors may be overly willing to risk investment, social planners would only be willing to accept higher viability chances given the greater total social costs with success.

From another perspective, if the scale of losses $L$ occurs at a level below the acceptable private maximum but above the social planner's maximum threshold,

$$
[p /(1-p)] M>L>[p /(1-p)](M-S)
$$

pioneering, while socially undesirable, will occur because of the crucial pioneer's narrower focus on her own private risk and returns. In general, such private decisions will be more socially suboptimal with greater total spillovers, $S$.

While establishing whether potential social benefits outweigh total costs must be considered on a case-by-case basis, it is clear that private actors, due to the divergence between private and social costs and benefits, may not fully understand and will not fully incorporate the overall social impact of their actions. Attractive private investments could thus yield projects with considerable net social costs. In sum, the private market may overinvest in rural areas relative to the social optimum, with the game-theoretic model underscoring the conclusions of the simple benefit/cost analysis above. In our scenario, a potential pioneer will jump too quickly into a virgin rural area, causing a pathdependent accumulation of social costs.

\section{RURAL SPRAWL}

In this section we overview general development trends in the Rocky Mountain West by first distinguishing urban from rural land uses. We then review case study and empirical research from two studies that support the notion that rural land-use change is path dependent. Finally, we explore evidence suggesting the importance of accumulating social costs.

\subsection{Urban and Rural Land Use}

Though most of the nation is focused on urban sprawl (Waldie 2000), rural sprawl presents a more serious impact to the land base. There had been a consistent net rural-to-urban migration until the 1970s, but during the 1970s this trend reversed and large cities lost population while nonmetropolitan rural areas and small cities experienced rapid population growth (Fuguitt and Brown 
1991). This trend of urban-to-rural migration has been especially pronounced in the Rocky Mountain West (Cromartie 1994; Hansen et al. 2002; Johnson and Rasker 1995). From 1990 to 1998 , rural portions of counties grew faster than urban in over 60 percent of the counties in the west (Census Bureau 1999).

Rural sprawl is development that occurs outside of urban areas (e.g., outside city and town limits). An alarming trend is that Americans are consuming more land per person for a rural residence (Daniels 1999). It is characterized by low-density development and in the Rocky Mountains occurs usually in the form of one housing unit per 10 to 160 acres. For example, from 1960 to 1990 the area in Colorado consumed by exurban development grew three times faster than the population growth rate (Theobald 2000). This trend of low-density land consumption is also occurring in Idaha, Montana, Utah, and Wyoming (Odell, Theobald, and Knight 2003).

\subsection{Case Study: Colorado's East River Valley}

In the East River Valley near Gunnison, Colorado, low-density growth has resulted in rapid conversion of agricultural land that has doubled each decade since 1960 (Theobald, Gosnell, and Riebsame 1996). One of the main attractions for newcomers to the East River valley was the wideopen spaces and the green valleys of hay meadows - in short, the working landscape of the West. We mapped the locations of low-density, rural subdivisions since 1964 in Figure 3. There are three clusters of subdivisions. The most obvious cluster is mid-valley, which grew rapidly in the 1970s.

One factor that contributed to the clustering of subdivisions in that area is a new sanitation district that was required to support one of the subdivisions, built in 1970. The likelihood of development on adjacent parcels increased because the high cost of supplying the initial infrastructure and roads was borne by the first developer. At the same time, agricultural landowners on adjacent parcels incurred an increased level of "hassle." For example, gates were left open, adjacent residents' dogs chased cows, and trespass became more common. As more residential newcomers fill the valley, it has been more challenging to drive cattle to pasture. As the local agricultural community breaks down, further growth is spurred (Theobald 1995).

As low-density development ensues, the value of ranching land increases dramatically and there is an increasing fiscal pressure to sell. Using U.S. Census of Agriculture data, the market value of the average agricultural acre in Gunnison County (home to the East River Valley) began to diverge from the statewide average in the early 1970s. The gap has widened over the past three decades to its current valuation of $\$ 1,154$ per acre, roughly twice the statewide average value (Figure 4).

\subsection{Testing Development Patterns}

In a study of rural development patterns in Summit County, Colorado, we developed a spatiallyexplicit data set of buildings by aggregating individual private land ownership parcels (Theobald and Hobbs 1998). Using the U.S. Public Land Survey System grid (i.e., township/range, section, quarter-section), the number of buildings in each 160-acre quarter-section cell was counted at five-

year increments from 1900 to 1998 . The study explicitly tested for the distinction between smooth 
FIGURE 3

\section{East River Valley low-density subdivisions}

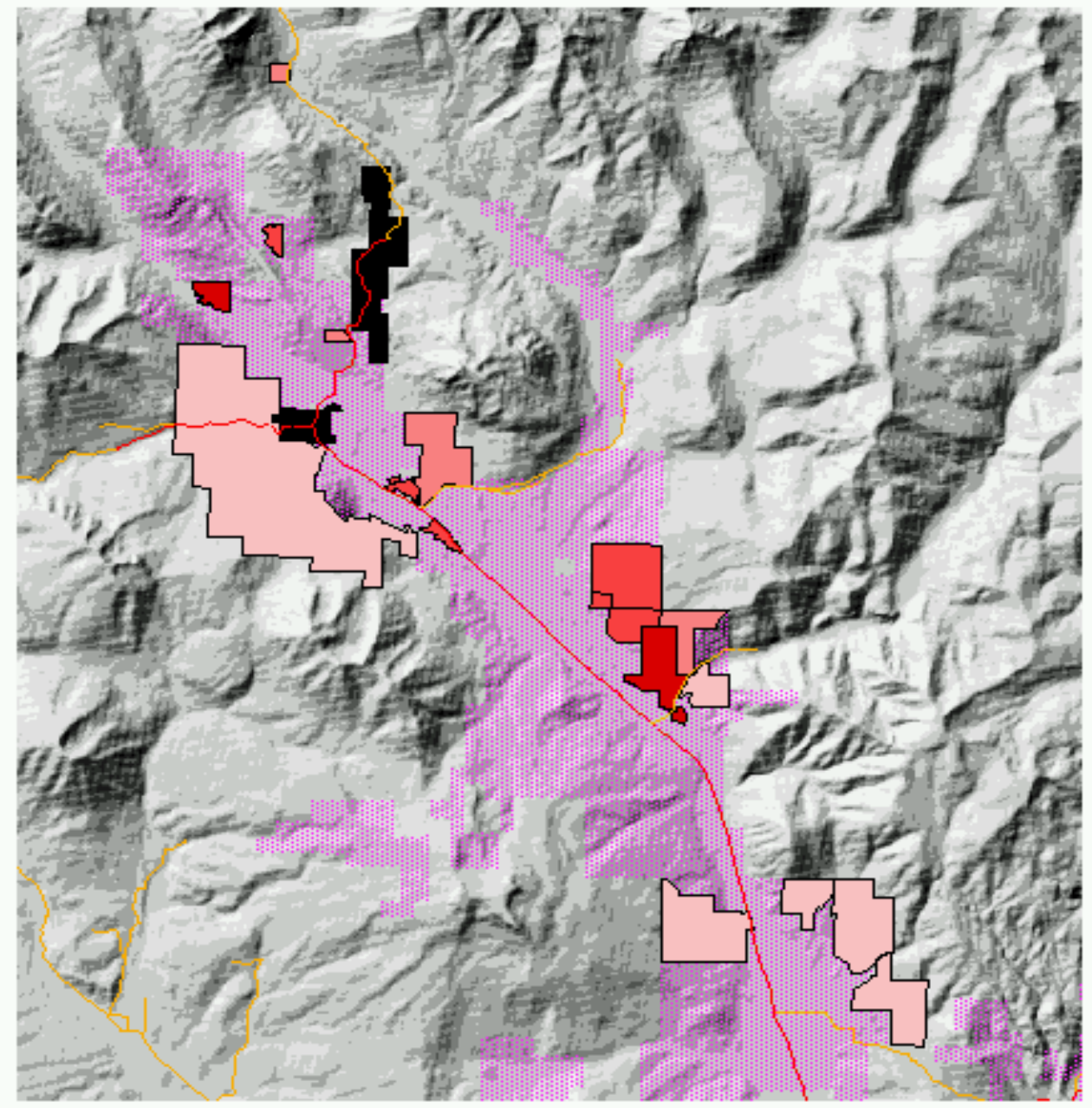

\section{Subdivisions}

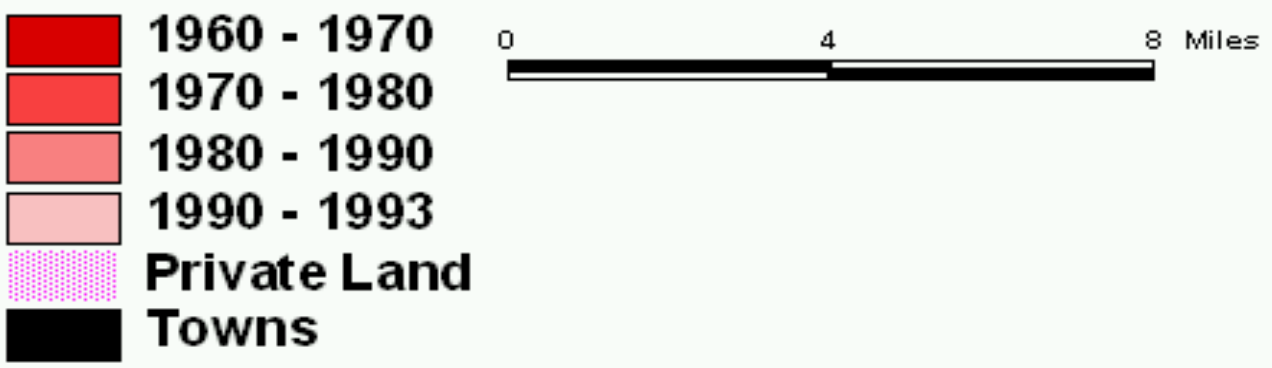


FIGURE 4

Average Land \& Building Value per Acre

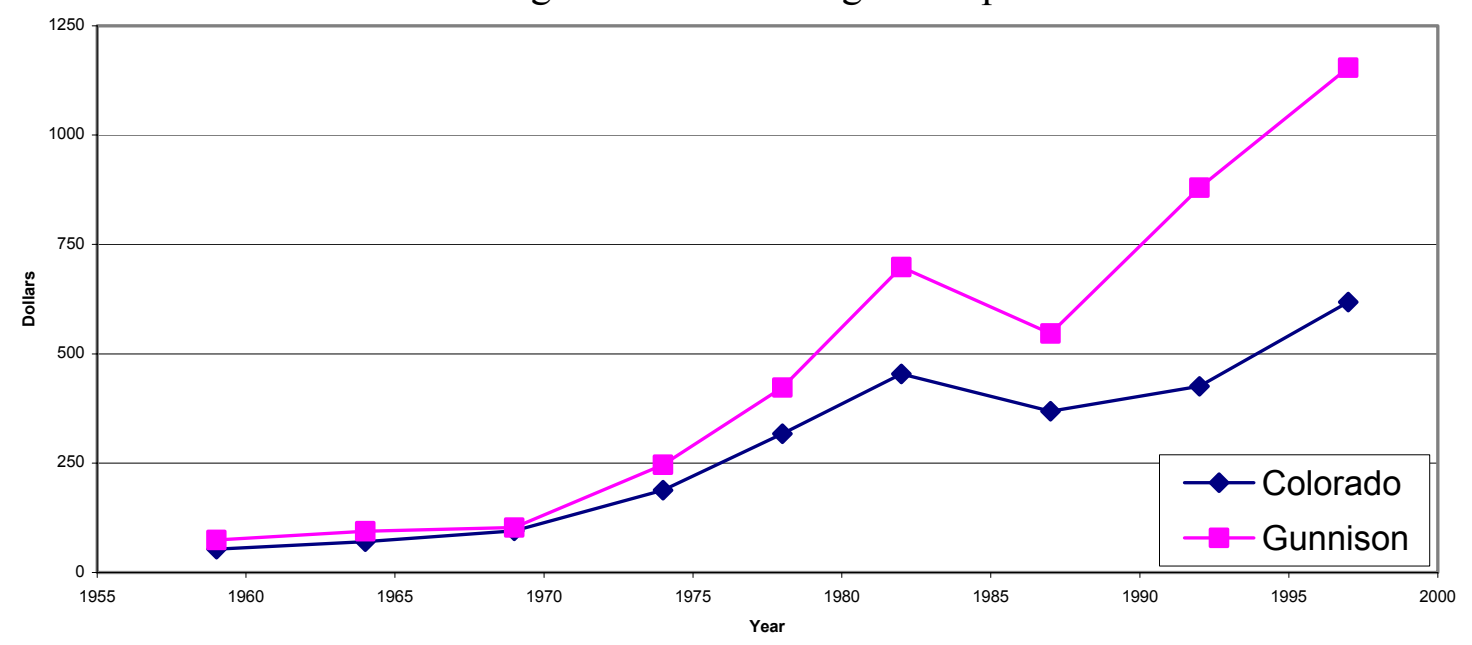

development gradients of municipality-based land-use patterns, such as that predicted by the von Thünen model, versus the path-dependent snowballing development based on isolated pioneers.

More specifically, we tested a logistic regression-based (LR) model that reflects basic smooth land rent assumptions against a spatially-explicit probability transition (ST) model. The LR model describes the relationship between development and the independent variables of distance to town, primary and secondary roads, where probability of development was expected to decrease with increasing distance from town and roads. The ST transition model captured the idea that a given cell was more likely to develop if its neighboring cells were developed and was based on a linear regression between a cell's neighborhood density at time $t$ and the cell's density at time $t+1$. A logistic regression was developed to describe the relationship between the presence/absence response variable (development/no development) and the independent variables of distance to town, primary and secondary roads. Probability of development $(y)$ decreases with increasing distance from town $\left(x_{1}\right)$ and primary and secondary roads $\left(x_{2}\right)$ :

$$
y=1 /\left(1+e^{-\left(1.60259+-0.00006 x_{1}+-0.00077 x_{2}\right)}\right)
$$

The average neighborhood housing density for each cell is calculated by summing the housing densities in the neighboring cells, divided by the number of cells that can possibly be developed. A range of circular neighborhoods with radii equal to 500,1,000, 1,500, and 2,000 meters was used to understand how sensitive the model was to varying neighborhood sizes. Cells with minimal developable land such as those occupied, for example, by a large body of water or public land are not used in calculating densities.

We evaluated the accuracy of the models using correlation and similarity of spatial overlap (Jaccard's coefficient) between the modeled and known distribution of development for 1975 to 1995 (Table 1). The similarity coefficient for the ST models was generally higher than for the LR 


\section{TABLE 1}

Correlation and Similarity Between Actual (Existing) Development Patterns and Modeled Development Patterns, Averaged Over Five Time Steps from 1975 - 1995 (Theobald and Hobbs 1998).

\begin{tabular}{cccc}
\hline \multicolumn{2}{c}{ Model } & Correlation & Similarity \\
\hline \multicolumn{2}{c}{ Logistic Regression } & 0.5285 & 0.685 \\
Spatial Transition & $500 \mathrm{~m}$ & 0.5937 & 0.745 \\
& $1,000 \mathrm{~m}$ & 0.5352 & 0.737 \\
& $1,500 \mathrm{~m}$ & 0.5609 & 0.717 \\
& $2,000 \mathrm{~m}$ & 0.5369 & 0.677 \\
\hline
\end{tabular}

\section{TABLE 2}

Comparison of the Development Footprint (Number of Developed Acres) Between Observed and Modeled Results Averaged Over 500 Iterations. Models that Had the Observed ("Truth") Values Within the Standard Deviations are Flagged (*), with Standard Deviations Below (Theobald and Hobbs 1998).

\begin{tabular}{lrrrrr}
\hline & \multicolumn{5}{c}{ Developed acres in } \\
\cline { 2 - 6 } Year & \multicolumn{1}{c}{1975} & 1980 & \multicolumn{1}{c}{1985} & \multicolumn{1}{c}{1990} & \multicolumn{1}{c}{1995} \\
\hline Observed & 29,164 & 32,018 & 34,598 & 36,718 & 38,565 \\
Logistic Regression & 35,459 & 38,140 & 4,024 & 41,156 & 42,634 \\
Spatial Transition 500 & $* 28,900$ & 29,577 & 29,808 & 29,808 & 29,808 \\
Spatial Transition 1,000 & 30,623 & 33,575 & $* 35,468$ & $* 36,524$ & $* 37,299$ \\
Spatial Transition 1,500 & 31,305 & 35,278 & 38,010 & 39,213 & 40,239 \\
Spatial Transition 2,000 & 33,633 & 38,491 & 42,770 & 44,580 & 46,574 \\
\hline LGR stddev & 829.76 & $1,357.78$ & $1,464.34$ & $1,382.55$ & $1,581.91$ \\
ST 500 stdev & 390.19 & 610.12 & 716.22 & 716.22 & 716.22 \\
ST 1,000 stdev & 705.53 & 953.18 & $1,320.29$ & $1,442.74$ & $1,545.98$ \\
ST 1,500 stdev & 628.80 & $1,158.79$ & $1,826.09$ & $1,992.70$ & $2,330.54$ \\
ST 2,000 stdev & 878.71 & $1,481.60$ & $3,009.32$ & $3,038.57$ & $4,118.18$ \\
\hline
\end{tabular}

developed area, as well as the lower incremental costs of providing infrastructure near alreadydeveloped areas.

The greater likelihood of development in areas that are adjacent to already developed areas is captured in a wide range of land-use change models (e.g., Clarke, Gaydos, and Hoppen 1997; Theobald in press; White and Engelen 1993). A number of more complex models have been developed that incorporate possible direct costs and benefits within an explicit economic framework (e.g., Landis and Zhang 1998; Verburg et al. 2002), but few of these focus on residential development in rural areas, partly due to the sparseness of data. An excellent review of these approaches and issues is provided in Irwin and Geoghegan (2001).

\subsection{Ecosystem and Infrastructural Costs}

There is heightened concern about the impacts of development on the natural resource base, causing habitat degradation and fragmentation of habitat (Hansen et al. 2002; LaGro 1994; Rasker 
and Hackman 1996; Stillwell 1987; Stroud 1983; Theobald, Miller, and Hobbs 1997). A main challenge in showing the accumulating costs of development to the environment is commonly known as the cumulative effects problem, or the "tyranny of small decisions made singly" (Kahn 1966, p. 23). While each individual land-use change results in an apparently minor effect, the accumulation of these changes over time and within a watershed may constitute a major impact (Edwards and Abivardi 1998; Theobald, Miller, and Hobbs 1997).

Research on whole ecosystem-level impacts from development is emerging (Baron et al. 2000), but most research on the impacts of land-use changes has been conducted for aquatic systems because watersheds neatly integrate land use and landscape changes (Griffith, Omernik and Woods 1999; Medina 1990). Even though development modifies only a small percentage of the landscape, especially in rural residential development, the modification of land cover results in a "flashier" hydrological response and has generated concern over possible increased probabilities and impacts from flooding (Leith and Whitfield 2000).

Potential degradation of water quality has also received considerable attention. For example, Magee et al. (1999) found that wetlands in urbanizing watersheds are floristically degraded and Wang et al. (2000) found that urbanization impacts are more severe than historical agricultural land use practices. In addition to sediment loading from increased road building, especially on steep hillsides, nutrient loading from additional septic systems associated with low-density residences in a watershed has generated concern (Stark, Nuckols, and Rada 1999; Wernick, Cook, and Schreir 1998). Finally, development of biological integrity indices that are sensitive to landscape changes is a vigorous research area (e.g., Hawkins et al. 2000; Jones et al. 2000; Wente 2000).

In terms of infrastructural costs, Brueckner (2000) highlights the fact that "infrastructure is priced approximately at average cost rather than marginal cost. . . [B]y undercharging new homeowners for the infrastructure costs they generate, the current system of public finance leads to urban sprawl." The divergence between marginal and average infrastructural costs is even greater in rural settings, as isolated developments can not benefit from the economies of scale inherent in more clustered urban contexts. Such a situation is particularly apparent in the noted case of firefighting, as protecting sprawling rural residences during wildfires can consume a disproportionate amount of public resources. Furthermore, the pioneer-led replication of such residential development also increases the likelihood of such wildfires in the first place. In general, the implicit subsidy of infrastructure's average cost pricing in rural residential development is exceptionally high.

In the Rocky Mountain West, this diverging development pattern is indeed resulting in considerable infrastructural subsidies for residential development in low-density rural areas, given that the region's towns have much lower per capita costs given their relative density (Jones, Theobald, and Sullins 2002). A review of 47 studies showed that residential property lost an average of 17 cents for each dollar of tax revenues, while the undeveloped alternative of agricultural and open space provided an average surplus of 69 cents (Haggerty 1997; Haggerty 1998). More recent work focused on Colorado finds that dispersed rural residential development costs county governments and schools $\$ 1.65$ for every dollar of new revenue produced (Coupal and Seidl 2003). Yet the pioneer still makes her decision based on her own narrow costs versus benefits. Any subsidy will reduce the costs relative to the benefits and make pioneering as well as following even more attractive. However, true social costs must include the effective subsidy provided by other private 
and public entities alongside the noted ecological costs. Superficially benign private decisions can thus create significant social cost burdens.

\section{CONCLUSIONS}

This paper argues that the relative benefit/cost incentive structure indicates that private pioneers will tend to create cycles of rural sprawl to the detriment of overall social welfare in the Rocky Mountain West. Infrastructural subsidies may worsen such cycles. The game-theoretic model indicates that first-movers face a disproportionate and fleeting share of benefits while incorporating only a narrow slice of the eventual costs of their pioneering efforts. Given such divergence between the private and social benefit-cost structure, pioneering encroachment into undeveloped areas is more pervasive than is socially optimal. Empirical findings on land-use intensity, path dependence, and accumulating external environmental costs confirm these theoretical hypotheses, indicating that rural sprawl may be both an understandable yet social-welfare-reducing phenomenon. Recent fire season experiences underline the likely divergences between private and social costs.

These divergences create a significant market failure; private market decisions will continue producing pioneers and followers despite the fact that the social costs of their actions exceed social benefits. The resultant welfare reduction will tend to grow with each new residential footprint in low-density rural areas. Given that the source of much of these welfare reductions are divergences between private and social costs, the clear policy prescription is to have rural residents face the full social cost of their residential decisions. Marginal cost pricing of service and infrastructure provision would mitigate the effects of current inefficient pricing policies. Relatedly, fire hazard fees could be assessed in forest fringe areas to offset local, state, and federal costs of potential firefighting efforts. Ecosystem damage, especially long-term, may be more difficult to properly assess, but this paper suggests that pioneering residences in undeveloped areas are likely to have particularly pernicious ecosystem effects, both in themselves and through subsequent followers. Therefore, particularly high development fees could be placed on especially "innovative" location decisions.

This paper more generally also presents a case for a broader consideration of land-use planning in previously undeveloped rural areas, especially given potential rent-seeking behavior through land speculation and/or rural agricultural subsidies. Using continuing work on contingent valuation of natural resources (e.g., Loomis 1997), the ecological impact of innovative and ensuing development is clearly quantifiable. As purely private decisions have been shown to be suboptimal, a planning framework incorporating broader social and ecological costs could substantially improve current and future welfare.

\section{REFERENCES}

Baron, J.S., D.M. Theobald, and D. Fagre, 2000. "Management of Land Use Conflicts in the United States Rocky Mountains," Mountain Research and Development 20(1), 24-27.

Baron, J.S., H.M. Rueth, A.M. Wolfe, K.R. Nydick, E.J. Alstott, J.T. Minnear, and B. Moraska, 2000. "Ecosystem Responses to Nitrogen Deposition in the Colorado Front Range," Ecosystems 3(4), 352-368. 
Baumol, W.J., 1963. "Interaction of Public and Private Decisions," in H.S. Schaller (ed.), Public Expenditure Decisions in the Urban Community. Johns Hopkins Press: Baltimore, MD.

Blair, J., 1995. Local Economic Development. Sage: Thousand Oaks, CA.

Brueckner, J.K., 2000. “Urban Sprawl: Diagnosis and Remedies,” International Regional Science Review, 23(2) 160-171.

Census Bureau, 1999. County Population Estimates. U.S. Department of Commerce: Washington, D.C.

Clarke, K.C., L. Gaydos, and S. Hoppen, 1997. "A Self-Modifying Cellular Automaton Model of Historical Urbanization in the San Francisco Bay Area," Environment and Planning B 24, 247-261.

Coupal, R. and A. Seid1, 2003. "Rural Land Use and Your Taxes: The Fiscal Impact of Rural Residential Development in Colorado," Agricultural and Resource Policy Report 03-03. Colorado State University: Fort Collins, CO.

Cromartie, J. 1994, "Recent Demographic and Economic Changes in the West," statement before the House Committee on Natural Resources Hearing on "The Changing Needs of the West," April 7. Economic Research Service, U.S. Department of Agriculture: Washington, D.C.

and M. Nord, 1997. "Migration Contributes to Nonmetro Per Capita Income Growth," Rural Conditions and Trends 8(2), 40-45.

Daniels, T., 1999. “What to Do About Rural Sprawl?” Presented at The American Planning Association Conference, Seattle, Washington, April 28.

Duany, A., E. Pater-Zyberk, and J. Speck, 2000. Suburban Nation: The Rise and Sprawl and the Decline of the American Dream. North Point Press: Fort Collins, CO.

Edwards, P.J. and C. Abivardi, 1998. "The Value of Biodiversity: Where Ecology and Economy Blend," Biological Conservation 83(3), 239-246.

Fuguitt, G.V. and D.L. Brown, 1991. "Residential Preferences and Population Redistribution: 1972-1988," Demography 27, 589-600.

Griffith, G.E., J.M. Omernik and A.J. Woods, 1999. "Ecoregions, Watersheds, Basins, and HUCs: How State and Federal Agencies Frame Water Quality," Journal of Soil and Water Conservation 54(4), 666-677. 
Haggerty, M., 1997. “The Fiscal Impacts of Alternative Development Patterns: Broadwater and Gallatin Counties," Montana Policy Review Fall, 19-28.

, 1998. "Economic Values of Wildlife and Open Space," Available at http://ndis.nrel.colostate.edue/ndis/economics.htm.

Hansen, A.J., R. Rasker, B. Maxwell, J.J. Rotella, J.D. Johnson, A.W. Parmenter, L. Langner, W.B. Cohen, R.L. Lawrence and M.P.V. Kraska, 2002. "Ecological Causes and Consequences of Demographic Change in the New West," Bioscience 52(2), 151-162.

Harsanyi, J., 1968. "Games With Incomplete Information Played by Bayesian Players, I, II, III," Management Science 14, 159-182, 320-334, 486-503.

Hawkins, C.P., R.H. Norris, J.N. Hogue and J.W. Feminella, 2000. "Development and Evaluation of Predictive Models for Measuring the Biological Integrity of Streams," Ecological Applications 10(5), 1456-1477.

Irwin, E.G. and J. Geoghegan, 2001. "Theory, Data, Methods: Developing Spatially Explicit Economic Models of Land Use Change," Agriculture Ecosystems \& Environment 85(1-3), 7-23.

Johnson, J.D. and R. Rasker, 1995. "The Role of Economic and Quality of Life Values in Rural Business Location," Journal of Rural Studies 11(4), 405-416.

Jones, K.B., D.T. Heggem, T.G. Wade, A.C. Neale, D.W. Ebert, M.S. Nash, M.H. Mehaffey, K.A. Hermann, A.R. Selle, S. Augustine, I.A. Goodman, J. Pedersen, D. Bolgrien, J.M. Viger, D. Chiang, C.J. Lin, Y.H. Zhong, J. Baker, and R.D. Van Remortel, 2000. "Assessing Landscape Condition Relative to Water Resources in the Western United States: A Strategic Approach," Environmental Monitoring and Assessment 64(1), 227245.

Jones, J., D.M. Theobald, and M. Sullins, 2002. "The Lay of the Land," in R.L. Knight, W. Gilgert, and E. Marston (eds.), Culture, Economics, and Ecology of Ranching West of the 100th Meridian, pp. 25-34. Island Press: Washington, D.C.

Kahn, A.E., 1966. "The Tyranny of Small Decisions: Market Failures, Imperfections, and the Limits of Economics," KYKLOS 19, 23-45.

Kahneman, D., J.L. Knetsch, R.H. Thaler, 2000. "Fairness as a Constraint on Profit Seeking: Entitlements in the Market," in D. Kahnemann and A. Tversky (eds.), Choices, Values, and Frames. Cambridge University Press: Cambridge, UK.

Lagro, J.A., 1994. "Population-Growth Beyond the Urban Fringe - Implications for Rural Land-Use Policy," Landscape and Urban Planning 28(2-3), 143-158.

Landis, J. and M. Zhang, 1998. "The Second Generation of the California Urban Futures Model. Part 1: Model Logic and Theory," Environment and Planning B 25(5), 657-666. 
Leith, R.M. and P.H. Whitfield, 2000. "Some Effects of Urbanization on Streamflow Records in a Small Watershed in the Lower Fraser Valley, BC," Northwest Science 74(1), 69-75.

Loomis, J., 1997. "Use of Non-Market Valuation Studies in Water Resources Management Assessments," Water Resources Update 109, 5-9.

Magee, T.K., T.L. Ernst, M.E. Kentula, K.A. Dwire, 1999. "Floristic Comparison of Freshwater Wetlands in an Urbanizing Environment," Wetlands 19(3), 517-534.

Medina, A.L., 1990. "Possible Effects of Residential Development on Streamflow, Riparian Plant-Communities, and Fisheries on Small Mountain Streams in Central Arizona," Forest Ecology and Management 33-4(1-4), 351-361.

Nelson, A., 1992. “Characterizing Exurbia,” Journal of Planning Literature 6(4), 350-368.

Odell, E.A., D.M. Theobald, and R.L. Knight, 2003. "Incorporating Ecology Into Land Use Planning: The Songbirds' Case for Clustered Development," Journal of the American Planning Association 69(1), 72-82.

Power, T.M., 1996. Lost Landscapes and Failed Economies: The Search for a Value of Place. Island Press: Washington, D.C.

Pyle, L.A., 1985. "The Land Market Beyond the Urban Fringe," Geographical Review 75(1), 32-43.

Rasker, R. and A. Hackman, 1996. "Economic Development and the Conservation of Large Carnivores," Conservation Biology 10(4), 991-1002.

Riebsame, W.E., H. Gosnell, and D.M. Theobald, 1996. "Land Use and Landscape Change in the Colorado Mountains: Theory, Scale, and Pattern," Mountain Research and Development 16(4), 395-405.

Stark, S.L., J.R. Nuckols, and J. Rada, 1999. "Using GIS to Investigate Septic System Sites and Nitrate Pollution Potential," Journal of Environmental Health 61(8), 15-20.

Stillwell, H.D., 1987. "Environmental Impacts and Site Constraints of Mountain Resort Development," Papers and Proceedings of Applied Geography 10, 297-305.

Stroud, H.B., 1983. "Environmental Problems Associated with Large Recreational Subdivisions," The Professional Geographer 35(3), 303-313.

Theobald, D.M., 1995. "Morphology and Effects of Mountain Land Use Change in Colorado: A Multi-Scale Landscape Analysis," Unpublished Ph.D. dissertation, Department of Geography, University of Colorado. 
, 2000. "Fragmentation by Inholdings and Exurban Development," in R.L. Knight, F.W. Smith, S.W. Buskirk, W.H. Romme, and W.L. Baker (eds.), Forest Fragmentation in the Southern Rocky Mountains. University Press of Colorado: Boulder, CO. , 2002. "Growth Along the Western U.S. Forest Fringe," Unpublished Natural Resource Ecology Lab Report, Colorado State University.

, 2003. "Targeting Conservation Action through Assessment of Protection and Exurban Threats.” Conservation Biology 17(6): 1624-1637.

Theobald, D.M., H. Gosnell, and W.E. Riebsame, 1996. "Land Use and Landscape Change in the Colorado Mountains: A Case Study of the East River Valley," Mountain Research and Development 16(4), 407-418.

Theobald, D.M. and N.T. Hobbs, 1998. "Forecasting Rural Land Use Change: A Comparison of Regression- and Spatial Transition-Based Models," Geographical \& Environmental Modeling 2(1), 57-74.

Theobald, D.M., J.R. Miller, and N.T. Hobbs, 1997. "Estimating the Cumulative Effects of Development on Wildlife Habitat," Landscape and Urban Planning 39(1), 25-36.

Verburg, P.H., W. Soepboer, A. Veldcamp, R. Limpiada, V. Espaldon, and S.S.A. Mastura, 2002. "Modeling the Spatial Dynamics of Regional Land Use: The CLUE-S Model," Environmental Management 30(3), 391-405.

Waldie, D.J., 2000. “Do the Voters Really Hate Sprawl?” New York Times. March 3 rd

Wang, L.Z., J. Lyons, P. Kanehl, R. Bannerman, and E. Emmons, 2000. "Watershed Urbanization and Changes in Fish Communities in Southeastern Wisconsin Streams. Journal of the American Water Resources Association," 36(5): 1173-1189.

Weiler, S., 2000. "Pioneers and Settlers in Lower Downtown Denver: Private Risk and Public Benefits in Urban Redevelopment," Urban Studies 37(1), 167-179.

Wente, S.P., 2000. "Proximity-Based Measure of Land Use Impacts to Aquatic Ecosystem Integrity," Environmental Toxicology and Chemistry 19(4), 1148-1152.

Wernick, B.G., K.E. Cook, and H. Schreier, 1998. "Land Use and Streamwater Nitrate-N Dynamics in an Urban-Rural Fringe Watershed," Journal of the American Water Resources Association 34(3), 639-650.

White, R. and G. Engelen, 1993. "Cellular Automata and Fractal Urban Form: A Cellular Modeling Approach to the Evolution of Urban Land-Use Patterns," Environment and Planning A 25, 1175-1199. 
Wilkin, D.C. and D.R. Iams, 1990. "Characteristics and Attitudes of Pima County Residents Related to Urban Expansion into Rural Areas," Landscape Journal 9(1), 42-46. 